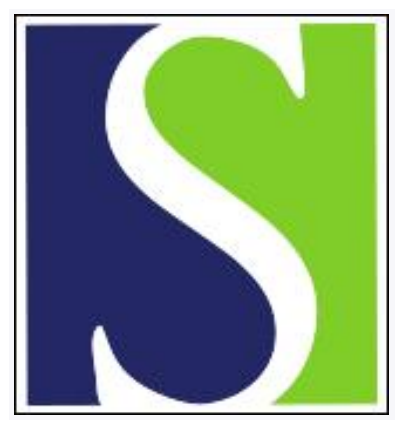

Scand J Work Environ Health 2003;29(4):270-279

https://doi.org/10.5271/sjweh.731

Issue date: Aug 2003

Trends in the Danish work environment in 1990-2000 and their associations with labor-force changes

by Burr H, Bjorner JB, Kristensen TS, Tüchsen F, Bach E

Affiliation: National Institute of Occupational Health, Lersø Parkallé 105, DK-2100 Copenhagen Ø, Denmark. hb@ami.dk

Refers to the following texts of the Journal: 2001;27(2):97-105

2003;29(1):35-39 2000;26(5):414-420 1996;22(3):165-175

The following articles refer to this text: SJWEH Supplements

2008;(5):22-26; SJWEH Supplements 2008;(6):83-90;

2009;35(4):284-293; SJWEH Supplements 2009;(7):5-14;

2010;36(6):435-444; 2012;38(2):120-133; 2016;42(2):153-161;

2017;43(2):146-154; 2017;43(3):241-249; 2019;45(2):174-182;

2020;46(5):498-507; 2021;47(5):335-348; 2022;48(4):302-311;

2023;49(2):95-98

Key terms: cleaning agent; computer use; Denmark; job control; job insecurity; labor force; noise; occupational exposure; surveillance study; work environment; work posture; workhours

This article in PubMed: www.ncbi.nlm.nih.gov/pubmed/12934720

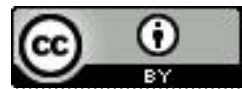




\title{
Trends in the Danish work environment in 1990-2000 and their associations with labor-force changes
}

\author{
by Hermann Burr, PhD, ${ }^{1}$ Jakob B Bjorner, PhD, ${ }^{1}$ Tage S Kristensen, DrMedSci, ${ }^{1}$ Finn Tüchsen, MSc, ${ }^{1}$ \\ Bsa Bach, $P h D^{1}$
}

\author{
Burr H, Bjorner JB, Kristensen TS, Tüchsen F, Bach E Trends in the Danish work environment in 1990-2000 and \\ their associations with labor-force changes. Scand J Work Environ Health 2003;29(4):270-279.
}

\begin{abstract}
Objectives The aims of this study were (i) to describe the trends in the work environment in 1990-2000 among employees in Denmark and (ii) to establish whether these trends were attributable to labor-force changes.

Methods The split-panel design of the Danish Work Environment Cohort Study includes interviews with three cross-sections of 6067, 5454, and 5404 employees aged 18-59 years, each representative of the total Danish labor force in 1990, 1995 and 2000. In the cross-sections, the participation rate decreased over the period (90\% in $1990,80 \%$ in $1995,76 \%$ in 2000). The relative differences in participation due to gender, age, and region did not change noticeably.

Results Jobs with decreasing prevalence were clerks, cleaners, textile workers, and military personnel. Jobs with increasing prevalence were academics, computer professionals, and managers. Intense computer use, long workhours, and noise exposure increased. Job insecurity, part-time work, kneeling work posture, low job control, and skin contact with cleaning agents decreased. Labor-force changes fully explained the decline in low job control and skin contact to cleaning agents and half of the increase in long workhours, but not the other work environment changes.

Conclusions The work environment of Danish employees improved from 1990 to 2000, except for increases in long workhours and noise exposure. From a specific work environment intervention point of view, the development has been less encouraging because declines in low job control, as well as skin contact to cleaning agents, were explained by labor-force changes.
\end{abstract}

Key terms cleaning agents, computer use, job control, job insecurity, noise, occupational exposure, surveillance studies, work posture, workhours.

Surveillance of the work environment needs to include both cross-sectional assessments at specific points in time and longitudinal assessments of changes in the work environment. Longitudinal assessments are important for the identification of new risk factors, for the evaluation of previous interventions, and for the quantification of the health impact of various hazards. From a public health point of view it is important to know the overall changes in the work environment. But from a specific work environment intervention point of view, it is necessary to analyze why these changes take place.

Observed changes in the work environment of the total labor force in a country is a result of within-job changes, as well as changes in the occupational distri- bution of the labor force. Within-job changes occur for specific jobs. Not only attempts to improve the work environment, but also new technology and new work organization can explain within-job changes in the work environment. For the total labor force, changes in the occupational distribution of the labor force may also explain changes of the work environment. We refer to these changes as labor-force changes. Imagine a past and present exposure to heavy lifting among a labor force consisting of only two jobs (table 1). In this hypothetical example, exposure to heavy lifting would change drastically among the total labor force even if the exposure in each job did not change, solely due to the altered occupational distribution of the labor force.

Reprint requests to: Dr Hermann Burr, National Institute of Occupational Health, Lersø Parkallé 105, DK-2100 Copenhagen Ø, Denmark. [E-mail: hb@ami.dk] 
Table 1. Hypothetical example: exposure to heavy lifting past and present in a labor force comprising only two jobs with considerable labor-force changes and no within-job changes.

\begin{tabular}{lcccc}
\hline & \multicolumn{2}{c}{ Past } & & Present \\
\cline { 2 - 4 } & $\begin{array}{c}\text { Proportion of } \\
\text { total labor force } \\
(\%)\end{array}$ & $\begin{array}{c}\text { Exposure to } \\
\text { heavy lifting } \\
(\%)\end{array}$ & & $\begin{array}{c}\text { Proportion of } \\
\text { total labor force } \\
(\%)\end{array}$ \\
\cline { 2 - 4 } Job 1 & 20 & 5 & 70 & $\begin{array}{c}\text { Exposure to } \\
\text { heavy lifting } \\
(\%)\end{array}$ \\
Job 2 & 80 & 40 & 30 & 5 \\
\hline Total labor force & 100 & 33 & 100 \\
\hline
\end{tabular}

From a work environment intervention point of view, it is important to evaluate whether the occupational health system, as set up by Danish legislation (ie, the Danish Work Environment Authority, company-based health and safety committees, and occupational health services) has improved the work environment. However, other explanations of changes must be eliminated, such as labor-force changes, new technology, or new work organization. In this study, we focused on whether trends in the Danish work environment can be explained by labor-force changes.

To our knowledge, only three national representative interview studies (1-3) have analyzed changes of a number of work environment factors over time. In addition, trends in workhours have been well described for several countries (4). We are aware of only one study that has distinguished between within-job and laborforce change (3).

In the Danish Work Environment Cohort Study it was possible to compare three representative cross-sections of employees from 1990, 1995 and 2000. In 1990, a random sample of the adult population was drawn, and employees were interviewed about their work. In 1995 and 2000, the 1990 panel was reinterviewed together with two additional random samples of newcomers in the labor force (ie, young people and immigrants). The Study therefore contained three representative cross-sections of the working population and two cohorts, a 1990-1995-2000 cohort and a 1995-2000 cohort. The Study made possible cross-sectional studies dealing with the prevalence of health problems $(5,6)$ or work environment (7) and follow-up studies relating the work environment to changes in health (8-11) or changes in labor-market status (12). The Danish Work Environment Cohort Study has also been used to generate exposure matrices (13) and to provide a reference population in case-referent studies (14).

One of the aims of our present study was to describe changes in the work environment among employees in Denmark from 1990 to 2000. Work environment factors were chosen to cover three different exposure areas (physical and chemical, ergonomic, and psychosocial),
1990

1995

2000

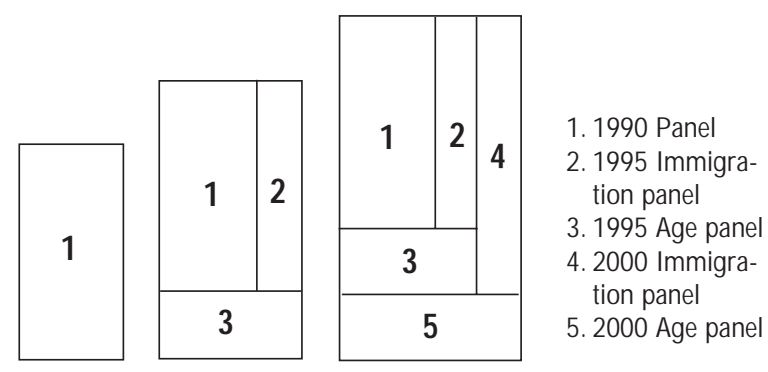

Figure 1. Panels of the Danish work environment cohort study in 1990, 1995, and 2000.

including workhours and use of computers. A second objective was to estimate to what extent any changes are attributable to (i) within-job changes or (ii) laborforce changes.

\section{Subjects and methods}

\section{Population}

The Danish Work Environment Cohort Study has used a split panel design (figure 1). The 1990 panel consisted of a simple random sample of people aged 18-59 years as of 1 October 1990 (table 2). The sample was drawn in 1990 from the central population register. The people in this panel were reinterviewed in 1995 and 2000 irrespective of participation in previous rounds.

Four other additional panels are represented in the study. The "1995 age panel" and "2000 age panel" were based on random samples drawn in 1995 and 2000, respectively. They consisted of people who were 18-22 years of age as of 1 October in the relevant year. These samples were drawn to adjust for the aging of the 1990 panel.

The "1995 immigration panel" and "2000 immigration panel" were based on samples drawn in 1995 and 2000 , respectively. They consisted of people who lived in the country on 1 October in the relevant year but who did not live in Denmark exactly 5 years earlier. These samples were drawn to adjust for migration. 
Table 2. Number of participants and response rates for the panels of the Danish Work Environment Cohort Study in 1990, 1995, and 2000.

\begin{tabular}{|c|c|c|c|c|c|c|}
\hline \multirow[b]{3}{*}{ Round sample } & \multirow{3}{*}{$\begin{array}{l}\text { Age (years) } \\
\text { Range }\end{array}$} & \multicolumn{4}{|c|}{ Sample } & \multirow{3}{*}{$\begin{array}{c}\text { Response } \\
\text { rate }\end{array}$} \\
\hline & & \multirow[b]{2}{*}{ Total a } & \multirow{2}{*}{$\begin{array}{l}\text { Deaths or } \\
\text { emigrations }^{b}\end{array}$} & \multicolumn{2}{|c|}{ Living in Denmark } & \\
\hline & & & & Total & Participants & \\
\hline \multicolumn{7}{|l|}{ All participants } \\
\hline \multicolumn{7}{|l|}{1990} \\
\hline 1990 panel & $18-59$ & 9700 & 47 & 9653 & 8664 & 90 \\
\hline \multicolumn{7}{|l|}{1995} \\
\hline Combined 1995 panel & $18-64$ & 11026 & 324 & 10702 & 8583 & 80 \\
\hline Original 1990 panel & $23-64$ & 9653 & 318 & 9335 & 7532 & 81 \\
\hline Additional 1995 immigrant panel & $23-64$ & 212 & 3 & 209 & 121 & 58 \\
\hline Additional 1995 age panel & $18-22$ & 1161 & 3 & 1158 & 930 & 80 \\
\hline \multicolumn{7}{|l|}{2000} \\
\hline Combined 2000 panel c & $18-69$ & 11955 & 518 & 11437 & 8583 & 75 \\
\hline Original 1990 panel c $^{c}$ & $28-69$ & 9342 & 405 & 8937 & 6754 & 76 \\
\hline Original 1995 immigrant panel & $28-69$ & 209 & 40 & 169 & 103 & 61 \\
\hline Original 1995 age panel & $23-27$ & 1158 & 48 & 1110 & 841 & 76 \\
\hline Combined 1995 panel $^{c}$ & $23-69$ & 10709 & 493 & 10216 & 7698 & 75 \\
\hline Additional 2000 immigrant panel & $23-69$ & 289 & 8 & 281 & 171 & 61 \\
\hline Additional 2000 age panel & $18-22$ & 957 & 17 & 940 & 716 & 76 \\
\hline \multicolumn{7}{|l|}{ Participants $<60$ years of age } \\
\hline \multicolumn{7}{|l|}{1990} \\
\hline 1990 panel & $18-59$ & 9700 & 47 & 9653 & 8664 & 90 \\
\hline \multicolumn{7}{|l|}{1995} \\
\hline Combined 1995 panel & $18-59$ & 9932 & 13 & 9919 & 7959 & 80 \\
\hline Original 1990 panel & $23-59$ & 8561 & 7 & 8554 & 6908 & 81 \\
\hline Additional 1995 immigrant panel & $23-59$ & 210 & 3 & 207 & 121 & 58 \\
\hline Additional 1995 age panel & $18-22$ & 1161 & 3 & 1158 & 930 & 80 \\
\hline \multicolumn{7}{|l|}{2000} \\
\hline Combined 2000 panel c $^{c}$ & $18-59$ & 9919 & 98 & 9821 & 7428 & 76 \\
\hline Original 1990 panel c $^{c}$ & $28-59$ & 7362 & 21 & 7341 & 5606 & 76 \\
\hline Original 1995 immigrant panel & $28-59$ & 168 & 4 & 164 & 101 & 62 \\
\hline Original 1995 age panel & $23-27$ & 1158 & 48 & 1110 & 841 & 76 \\
\hline Combined 1995 panel $^{\mathrm{c}}$ & $23-59$ & 8688 & 73 & 8615 & 6548 & 76 \\
\hline Additional 2000 immigrant panel & $23-59$ & 274 & 8 & 266 & 164 & 62 \\
\hline Additional 2000 age panel & $18-22$ & 957 & 17 & 940 & 716 & 76 \\
\hline
\end{tabular}

a In 1995 and 2000: except those who emigrated or died during the previous round.

b In 1990: between sampling date (1 October) and date of interview (October - January next year); in 1995 and 2000: between date of interview in the previous round and date of interview in the actual round (October - January next year).

c Including seven people who re-immigrated after 1995, of which two participated. Among the participants $<60$ years, five people re immigrated after 1995, of which two participated.

People in the age and immigration panels from 1995 were reinterviewed in 2000 irrespective of participation in the first round. The relative size of each panel reflected the proportion of the relevant groups of the total population-each panel representing around 0.003 of the national population.

The participation in the study was high, but it declined, from $90 \%$ to $76 \%$, among those in the panels aged 18 to 59 years (table 2). The participation of the immigration panels was much lower in each of the rounds. Participation was highest among the women, people in their 30s, and in rural areas (table 3). Participation was the lowest among the men, people aged 1829 years in 1990, and people in their 50s in 1995 and 2000 , and in the city of Copenhagen. In a multiple regression analysis, a log binominal model was used to estimate the prevalence proportion ratios (15). The regression analysis revealed that region played a major role for participation in the study in all three rounds (table 3). The relative differences in participation increased slightly from 1990 to 2000.

\section{Variables}

Data on age, gender, and region were obtained from the central population register. A regional classification based on municipality codes was used (16). All the other variables were based on telephone interviews with the respondents at home-or, if not possible, personal interviews in the respondents' homes. The interviewers were staff of the Danish National Social Research Institutes Survey Unit (SFI Survey) with extensive experience in interviewing. They received 6 hours of training with the questionnaires used, and the researchers and interview managers took part in this training. 
Table 3. Participants in the Danish Work Environment Cohort Study by gender, age, and region—proportion of participants in the total population. Participation, prevalence proportion ratios (PPR), was predicted by gender, age, and region in a multiple logistic regression analysis.

\begin{tabular}{|c|c|c|c|c|c|c|c|c|c|}
\hline \multirow{3}{*}{ Characteristic } & \multicolumn{3}{|c|}{1990} & \multicolumn{3}{|c|}{$1995^{a}$} & \multicolumn{3}{|c|}{2000} \\
\hline & \multicolumn{2}{|c|}{ Participants } & \multirow{2}{*}{$\begin{array}{c}\text { Participation }{ }^{\mathrm{b}} \\
\text { (PPR) }\end{array}$} & \multicolumn{2}{|c|}{ Participants } & \multirow{2}{*}{$\begin{array}{c}\text { Participation }{ }^{\mathrm{b}} \\
\text { (PPR) }\end{array}$} & \multicolumn{2}{|c|}{ Participants } & \multirow{2}{*}{$\begin{array}{c}\text { Participation }{ }^{b} \\
\text { (PPR) }\end{array}$} \\
\hline & $\mathrm{N}$ & $\%^{c}$ & & $\mathrm{~N}$ & $\%^{c}$ & & $\mathrm{~N}$ & $\%^{c}$ & \\
\hline \multicolumn{10}{|l|}{ Gender } \\
\hline Female & 4341 & 0.29 & 1 & 4020 & 0.26 & 1 & 3835 & 0.25 & 1 \\
\hline Male & 4323 & 0.28 & 0.97 & 3939 & 0.25 & 0.98 & 3593 & 0.23 & 0.94 \\
\hline \multicolumn{10}{|l|}{ Age } \\
\hline $18-29$ years & 2704 & 0.29 & 0.97 & 2369 & 0.26 & 0.99 & 1989 & 0.24 & 0.98 \\
\hline 30-39 years & 2157 & 0.29 & 1 & 2032 & 0.26 & 1 & 1994 & 0.24 & 1 \\
\hline 40-49 years & 2160 & 0.28 & 0.98 & 1942 & 0.25 & 0.97 & 1777 & 0.24 & 0.98 \\
\hline 50-59 years & 1643 & 0.30 & 0.98 & 1616 & 0.25 & 0.97 & 1668 & 0.22 & 0.93 \\
\hline \multicolumn{10}{|l|}{ Region } \\
\hline Rural & 2667 & 0.29 & 1 & 2540 & 0.27 & 1 & 2293 & 0.25 & 1 \\
\hline \multicolumn{10}{|l|}{ Gities } \\
\hline $10000-100000$ inhabitants & 2017 & 0.29 & 0.98 & 1905 & 0.27 & 0.97 & 1819 & 0.25 & 0.98 \\
\hline$>100000$ inhabitants & 1109 & 0.30 & 1.00 & 1053 & 0.27 & 0.97 & 989 & 0.25 & 0.99 \\
\hline \multicolumn{10}{|l|}{ Metropolitan area } \\
\hline Other & 688 & 0.30 & 0.99 & 596 & 0.25 & 0.92 & 544 & 0.23 & 0.93 \\
\hline Suburbs & 1252 & 0.29 & 0.94 & 1046 & 0.24 & 0.89 & 887 & 0.21 & 0.87 \\
\hline Gity & 931 & 0.25 & 0.87 & 808 & 0.20 & 0.76 & 896 & 0.21 & 0.81 \\
\hline
\end{tabular}

a Eeven participants in 1995 were not classified with regard to region.

b PPR calculated in a multiple logistic regression.

c Proportion of participants of total national population. See Statistics Denmark: www.dst.dk.

On the basis of information on job, education, and social status, the participants were classified into job groups by means of the 1968 Danish extended version (17) of the International Standard Classification of Occupations (ISCO).

In this paper, we covered the following three aspects of the work environment with two variables each: (i) physical, thermal and chemical, (ii) ergonomic, and (iii) psychosocial. In addition, we covered workhours and computer use. The selected variables had the ability to discriminate and reasonable validity and were important predictors of health outcomes. Part-time work and long workhours defined the potential length of exposure for several work environment factors. Computer use may not only cause musculoskeletal complaints (18), but also affect the work organization and work content. Job control (19-21), job insecurity $(22,23)$, and sedentary work (24) were considered important contributory factors in the development of several health problems, for example, cardiovascular diseases. Kneeling work posture was related to musculoskeletal complaints (25). Occupational noise and skin contact to cleaning agents (26) had been subject to efforts to reduce these exposures and have well established health consequences.

The length of workhours was based on the total of paid and unpaid weekly workhours for the main job and-as appropriate-the second job. Part-time work was defined as work lasting less than 30 hours a week.
Long workhours was defined as working $\geq 48$ hours per week.

Intense computer use was defined as using a personal computer at work and working at least three-fourths of the workhours with a visual display unit (VDU).

A job insecurity scale was constructed on the basis of the following four questions: "Are you worried about becoming unemployed?", "Do you worry about being involuntarily transferred to another job?", "Do you worry that the implementation of new technology will make you redundant?", and "Do you worry about the difficulty of finding a new job with your present qualifications?" Cronbach's alpha for the three rounds equaled $0.61-0.58$, and the interitem correlation varied between 0.16 and 0.36 . Job insecurity was defined as belonging to the highest quartile of the scale.

A job control scale was constructed on the basis of the following three questions: "Do you participate in planning your own work (eg, what to do, how to do it, or who to work with)?", "Does your work require that you repeat the same work tasks many times per hour?", and "Is your work varied?" The Cronbach's alpha for the three rounds equaled $0.60-0.67$, and the interitem correlation varied between 0.29 and 0.47 . Low job control was defined as belonging to the lowest quartile of the scale.

Kneeling work posture was defined as answering at least "one-fourth of the workhours" to the question "Does your work involve squatting or kneeling?" 
Sedentary work was defined as answering "Almost all workhours" to the question "Does your work involve sitting?"

Noise exposure was defined as exposure for at least "one-fourth of the workhours" to the question "Are you exposed to noise that is so loud you have to raise your voice when more people are together?"

Cleaning agents was defined as having exposure of at least "one-fourth of the workhours" to the question "Are you exposed to skin contact with cleaning agents or disinfectants?"

\section{Analyses}

Changes in the occupational distribution of the labor force from 1990 to 2000. The proportions of employees in jobs were analyzed by comparing the cross-sections of 1990 and 2000. In each round, the cross-sections consisted of employees aged 18-59 years. The number of employees in each cross-section was 6067 in 1990, 5523 in 1995, and 5404 in 2000. Job was defined by categories of the ISCO that were combined into 55 job groups covering two-thirds of the employees, the rest were divided into groups defined by the first three digits of the ISCO.

Changes of selected work environment factors from 1990 to 2000. The prevalence of the work environment factors among the employees was analyzed by comparing cross-sections from 1990, 1995, and 2000. In each round, the cross-sections consisted of employees aged 18-59 years. With calendar year as a continuous variable, we used logistic regression to analyze changes over time.

In order to distinguish between (i) changes attributable to labor-force changes and (ii) within-job changes, we did two things. First, we calculated the prevalences when the composition within jobs in 1995 and 2000 were standardized to be the same as in 1990. Second, we controlled for job category in the logistic regression of changes over time. The first three digits in the job classification of the ISCO in 1968 defined the job categories.

\section{Changes of selected work environment factors from 1990} to 2000 in selected jobs. In order to analyze whether changes in work environment factors occurred in all jobs or if these changes occurred in different directions in different jobs, we analyzed all the changes in nine important jobs. The jobs were selected to cover work with information, work with people, and work with materials requiring skills of various levels. The prevalences of the work environment factors among the employees were analyzed by comparing employees within the selected job titles in cross-sections from 1990, 1995, and
2000. In each round, the cross-sections consisted of employees aged 18-59 years. With calendar year as a continuous variable, we used a logistic regression to analyze changes over time.

\section{Results}

\section{Distribution of the labor force}

The distribution of employees into job groups changed from 1990 to 2000 (table 4). Among the office jobs, the proportion of clerks among the total number of employees dropped considerably after 1990 (from 9.6\% to $7.4 \%$ ), whereas the proportion of computer professionals, designers, academics, and managers increased. Among the service jobs, the proportion of cleaners decreased, whereas the proportion of salesmen and home help increased. Among the industrial jobs, the proportion of textile workers, printing workers, and compositors decreased.

\section{Changes in the work environment of the total population}

We found increases in the observed proportions of employees with intense computer use, long workhours, and noise exposure (table 5). The observed proportions of employees with job insecurity, part-time work, kneeling work posture, low job control, and skin contact with cleaning agents declined. The observed proportion of employees with sedentary work remained at the same level.

The declines in low job control and skin contact to cleaning agents were, to a large extent, explained by labor-force changes. For example, the observed proportion of employees with low job control declined from $22.0 \%$ in 1990 to $18.4 \%$ in 2000 . When we controlled for labor force changes, however, the proportion of employees in 2000 was $21.5 \%$-not significantly different from the level in 1990. A total of $84 \%$ of the change could be explained by labor-force changes. In addition about half of the change in long workhours was explained by labor-force changes.

The declines in part-time work, high job insecurity, and kneeling work posture were not explained by labor-force changes. Nor did labor-force changes explain the increases in intense computer use and loud noise.

\section{Changes in the work environment in selected jobs}

The prevalence of sedentary work and skin contact to cleaning agents changed in opposite directions in some of the selected jobs (table 6). In contrast to the overall absence of change in sedentary work (table 5), clerks experienced a decrease, whereas sales assistants 
Table 4. Proportion of total number of employees in increasing and declining jobs in Denmark, 1990 - 2000 - employees 18-59 years in each year.

\begin{tabular}{|c|c|c|c|c|}
\hline & \multicolumn{2}{|c|}{ Employees } & \multirow{2}{*}{\multicolumn{2}{|c|}{$\begin{array}{c}\text { Change } \\
\text { (from } 1990 \text { to 2000) }\end{array}$}} \\
\hline & \multirow{2}{*}{$\begin{array}{c}1990(\mathrm{~N}=5916) \\
(\%)\end{array}$} & \multirow{2}{*}{$\begin{array}{c}2000(\mathrm{~N}=5386) \\
(\%)\end{array}$} & & \\
\hline & & & Ratio $^{a}$ & $95 \% \mathrm{Cl}$ \\
\hline \multicolumn{5}{|c|}{ Jobs with a decreasing proportion of employees $(P<0.01)$} \\
\hline Gerks & 9.6 & 7.4 & 0.78 & $0.69-0.89$ \\
\hline Geaners & 2.8 & 1.6 & 0.58 & $0.44-0.74$ \\
\hline Textile workers & 0.6 & 0.2 & 0.29 & $0.14-0.58$ \\
\hline Repairmen (machines) & 0.3 & 0.1 & 0.24 & $0.08-0.72$ \\
\hline Compositors (printing industry) & 0.3 & $0.0^{\mathrm{b}}$ & 0.12 & $0.03-0.50$ \\
\hline Military personnel & 1.6 & 0.6 & 0.37 & $0.25-0.56$ \\
\hline \multicolumn{5}{|c|}{ Jobs with an increasing proportion of employees ( $P<0.01)$} \\
\hline Academics & 2.0 & 2.8 & 1.38 & $1.08-1.75$ \\
\hline Computer professionals & 1.0 & 2.3 & 2.39 & $1.75-3.27$ \\
\hline Designers & 0.3 & 0.7 & 2.20 & $1.25-3.87$ \\
\hline Managers & 4.6 & 5.8 & 1.26 & $1.07-1.48$ \\
\hline Sales people & 0.1 & 0.6 & 8.79 & $3.11-24.85$ \\
\hline Home help & 0.2 & 0.5 & 2.47 & $1.25-4.88$ \\
\hline
\end{tabular}

a Proportion 2000/proportion 1990 .

${ }^{b} 0.0 \%$ indicates a proportion below $0.05 \%$.

Table 5. Changes in selected work environment factors from 1990 to 2000 in Denmark—observed changes and changes controlled for labor-force change.

\begin{tabular}{|c|c|c|c|c|c|c|c|c|c|}
\hline \multirow{4}{*}{ Physical factors } & \multicolumn{5}{|c|}{ Employees aged 18-59 years } & \multirow{2}{*}{\multicolumn{2}{|c|}{ Trend 1990 to 1995 to 2000}} & \multirow{2}{*}{\multicolumn{2}{|c|}{$\begin{array}{l}\text { Relative change } \\
\text { from } 1990 \text { to } 2000^{\text {a }}\end{array}$}} \\
\hline & \multirow{3}{*}{$\begin{array}{l}1990 \\
(\mathrm{~N}=5929)\end{array}$} & \multicolumn{2}{|c|}{$\begin{array}{l}1995 \\
(\mathrm{~N}=5447)\end{array}$} & \multicolumn{2}{|c|}{$\begin{array}{l}2000 \\
(\mathrm{~N}=5404)\end{array}$} & & & & \\
\hline & & $\begin{array}{c}\text { Observed } \\
(\%)\end{array}$ & $\begin{array}{l}\text { Controlled } \\
\text { for labor- } \\
\text { force } \\
\text { change }^{b}\end{array}$ & $\begin{array}{c}\text { Observed } \\
\text { (\%) }\end{array}$ & $\begin{array}{l}\text { Controlled } \\
\text { for labor- } \\
\text { force } \\
\text { change }^{b}\end{array}$ & \multirow[t]{2}{*}{$\begin{array}{l}\text { Observed } \\
\text { (P-value) }\end{array}$} & $\begin{array}{l}\text { Controlled } \\
\text { for labor- } \\
\text { force } \\
\text { change }^{b}\end{array}$ & \multirow{2}{*}{$\begin{array}{l}\text { Observed } \\
\text { (\%) }\end{array}$} & \multirow{2}{*}{$\begin{array}{l}\text { Controlle } \\
\text { for labor- } \\
\text { force } \\
\text { change }^{b} \\
(\%)\end{array}$} \\
\hline & & & & & & & (P-value) & & \\
\hline \multicolumn{10}{|l|}{ Workhours } \\
\hline Part-time work & 13.4 & 11.6 & 11.8 & 9.2 & 9.7 & 0.000 & 0.000 & -32 & -28 \\
\hline Long workhours & 8.3 & 9.1 & 8.5 & 11.3 & 10.0 & 0.000 & 0.001 & 36 & 20 \\
\hline \multicolumn{10}{|l|}{ Computer use } \\
\hline Intense computer use & 4.4 & 11.3 & 11.7 & 20.9 & 20.5 & 0.000 & 0.000 & 371 & 361 \\
\hline \multicolumn{10}{|l|}{ Psychosocial factors } \\
\hline Low job control & 22.0 & 20.1 & 20.8 & 18.4 & 21.5 & 0.000 & 0.118 & -16 & -3 \\
\hline High job insecurity & 25.9 & 16.1 & 16.5 & 15.6 & 17.0 & 0.000 & 0.000 & -40 & -34 \\
\hline \multicolumn{10}{|l|}{ Ergonomic factors } \\
\hline Kneeling work posture & 17.0 & 12.1 & 12.0 & 13.4 & 13.4 & 0.000 & 0.000 & -21 & -21 \\
\hline Sedentary work & 19.6 & 15.4 & 15.6 & 18.5 & 17.7 & 0.101 & 0.001 & -5 & -9 \\
\hline \multicolumn{10}{|l|}{ Physical and chemical factors } \\
\hline Loud noise & 24.8 & 29.1 & 29.2 & 30.3 & 31.0 & 0.000 & 0.000 & 23 & 25 \\
\hline Cleaning agents, skin contact & 9.5 & 8.5 & 9.1 & 8.1 & 9.1 & 0.006 & 0.990 & -15 & -5 \\
\hline
\end{tabular}

a Difference between 2000 prevalence and 1990 prevalence as the percentage of the 1990 prevalence.

b A weight was given so that the weighted number of employees in each job in 1995 and 2000 was the same as in 1990.

experienced an increase (table 6). And, in contrast to the overall absence of change in skin contact to cleaning agents (table 5), cleaners experienced a decrease, while nurses reported an increase (table 6).

Regarding all the other work environment factors, the significant changes in the jobs were the same as the overall changes. The decreases in part-time work, kneeling work posture, and job insecurity also occurred in most of the selected jobs. This was also the case with the increases in intense computer use and loud noise. The increase in loud noise was highest in two nonindustrial jobs and among teachers and sales assistants. Regarding intense computer use and kneeling work posture, changes were only found in jobs in which the work 
Table 6. Work environment in Denmark during 1990-2000 in selected jobs.

\begin{tabular}{|c|c|c|c|c|c|c|c|c|c|}
\hline \multirow[b]{2}{*}{ Group of employees } & \multicolumn{9}{|c|}{ Employees aged $18-59$ years in each round } \\
\hline & $\begin{array}{l}\text { Part time } \\
\text { work } \\
\text { (\%) }\end{array}$ & $\begin{array}{l}\text { Long } \\
\text { work- } \\
\text { hours } \\
(\%)\end{array}$ & $\begin{array}{l}\text { Intensive } \\
\text { computer } \\
\text { use } \\
(\%)\end{array}$ & $\begin{array}{l}\text { Low job } \\
\text { control } \\
\text { (\%) }\end{array}$ & $\begin{array}{l}\text { High job } \\
\text { insecurity } \\
(\%)\end{array}$ & $\begin{array}{l}\text { Kneeling } \\
\text { work } \\
\text { posture } \\
(\%)\end{array}$ & $\begin{array}{l}\text { Sedentary } \\
\text { work } \\
(\%)\end{array}$ & $\begin{array}{l}\text { Loud } \\
\text { noise } \\
\text { (\%) }\end{array}$ & $\begin{array}{l}\text { Cleaning } \\
\text { agents, } \\
\text { skin contact } \\
(\%)\end{array}$ \\
\hline \multicolumn{10}{|c|}{ Engineers and architects } \\
\hline $1990(\mathrm{~N}=96)$ & 2 & 8 & 9 & 1 & 17 & 3 & 42 & 8 & 0 \\
\hline $1995(\mathrm{~N}=75)$ & 3 & 4 & 24 & 1 & 20 & 1 & 33 & 9 & 3 \\
\hline $2000(\mathrm{~N}=90)$ & 0 & 9 & 48 & 2 & 11 & 1 & 36 & 10 & 0 \\
\hline P-value & 0.279 & 0.902 & 0.000 & 0.514 & 0.341 & 0.327 & 0.413 & 0.676 & 0.964 \\
\hline \multicolumn{10}{|c|}{ Computer professionals } \\
\hline $1990(\mathrm{~N}=57)$ & 2 & 11 & 46 & 4 & 16 & 4 & 53 & 5 & 2 \\
\hline $1995(\mathrm{~N}=59)$ & 2 & 7 & 63 & 7 & 7 & 3 & 56 & 7 & 0 \\
\hline $2000(\mathrm{~N}=124)$ & 3 & 15 & 85 & 6 & 12 & 1 & 44 & 12 & 0 \\
\hline P-value & 0.511 & 0.309 & 0.000 & 0.635 & 0.672 & 0.208 & 0.175 & 0.118 & 0.891 \\
\hline \multicolumn{10}{|c|}{ Teachers (primary school) } \\
\hline $1990(\mathrm{~N}=169)$ & 26 & 8 & 1 & 2 & 26 & 8 & 4 & 40 & 0 \\
\hline $1995(\mathrm{~N}=135)$ & 10 & 4 & 1 & 0 & 6 & 4 & 1 & 51 & 1 \\
\hline $2000(N=174)$ & 6 & 6 & 1 & 2 & 8 & 9 & 3 & 68 & 1 \\
\hline P-value ${ }^{a}$ & 0.000 & 0.607 & 0.921 & 0.976 & 0.000 & 0.896 & 0.476 & 0.000 & 0.272 \\
\hline \multicolumn{10}{|l|}{ Nurses } \\
\hline $1990(\mathrm{~N}=113)$ & 34 & 1 & 0 & 9 & 18 & 24 & 4 & 12 & 19 \\
\hline $1995(\mathrm{~N}=105)$ & 28 & 1 & 0 & 4 & 7 & 18 & 0 & 10 & 12 \\
\hline $2000(\mathrm{~N}=117)$ & 14 & 1 & 2 & 6 & 5 & 16 & 3 & 8 & 29 \\
\hline P-value & 0.001 & 0.980 & 0.883 & 0.379 & 0.002 & 0.145 & 0.645 & 0.333 & 0.047 \\
\hline \multicolumn{10}{|l|}{ Cerks } \\
\hline $1990(\mathrm{~N}=565)$ & 21 & 3 & 15 & 19 & 32 & 1 & 54 & 10 & 0 \\
\hline $1995(\mathrm{~N}=446)$ & 15 & 1 & 40 & 17 & 19 & 1 & 41 & 14 & 1 \\
\hline $2000(\mathrm{~N}=400)$ & 11 & 3 & 62 & 17 & 23 & 0 & 46 & 12 & 0 \\
\hline P-value & 0.000 & 0.853 & 0.000 & 0.221 & 0.001 & 0.284 & 0.008 & 0.241 & 0.726 \\
\hline \multicolumn{10}{|l|}{ Smiths } \\
\hline $1990(\mathrm{~N}=218)$ & 0 & 7 & 0 & 18 & 21 & 42 & 2 & 50 & 6 \\
\hline $1995(\mathrm{~N}=206)$ & 1 & 7 & 1 & 14 & 14 & 41 & 2 & 55 & 11 \\
\hline $2000(\mathrm{~N}=163)$ & 1 & 10 & 4 & 19 & 15 & 39 & 3 & 61 & 10 \\
\hline P-value & 0.168 & 0.225 & 0.008 & 0.960 & 0.081 & 0.588 & 0.443 & 0.037 & 0.154 \\
\hline \multicolumn{10}{|l|}{ Sales assistants } \\
\hline $1990(\mathrm{~N}=161)$ & 35 & 1 & 1 & 22 & 17 & 13 & 8 & 10 & 6 \\
\hline $1995(\mathrm{~N}=174)$ & 40 & 0 & 5 & 39 & 18 & 9 & 8 & 18 & 10 \\
\hline $2000(\mathrm{~N}=133)$ & 17 & 1 & 20 & 25 & 14 & 11 & 16 & 18 & 5 \\
\hline P-value ${ }^{a}$ & 0.003 & 0.557 & 0.000 & 0.480 & 0.500 & 0.452 & 0.038 & 0.044 & 0.842 \\
\hline \multicolumn{10}{|l|}{ Ceaners } \\
\hline $1990(\mathrm{~N}=168)$ & 62 & 0 & 0 & 58 & 35 & 38 & 1 & 8 & 79 \\
\hline $1995(\mathrm{~N}=144)$ & 54 & 1 & 0 & 54 & 15 & 19 & 0 & 14 & 60 \\
\hline $2000(\mathrm{~N}=88)$ & 38 & 1 & 0 & 56 & 33 & 28 & 0 & 13 & 62 \\
\hline P-value ${ }^{a}$ & 0.000 & 0.248 &.. $\mathrm{~b}$ & 0.614 & 0.245 & 0.022 & 0.896 & 0.211 & 0.001 \\
\hline \multicolumn{10}{|l|}{ Drivers (freight) } \\
\hline $1990(\mathrm{~N}=98)$ & 5 & 19 & 0 & 41 & 22 & 5 & 19 & 16 & 2 \\
\hline $1995(\mathrm{~N}=105)$ & 7 & 36 & 0 & 34 & 14 & 4 & 18 & 13 & 2 \\
\hline $2000(\mathrm{~N}=113)$ & 4 & 36 & 0 & 33 & 9 & 7 & 24 & 16 & 5 \\
\hline P-value ${ }^{a}$ & 0.817 & 0.013 &.. $\mathrm{~b}$ & 0.230 & 0.007 & 0.402 & 0.402 & 0.957 & 0.176 \\
\hline
\end{tabular}

a P-value for continuous change over time.

b P-value could not be calculated.

environment factor was present in 1990. Among the selected jobs, the increase in long workhours was only found among drivers.

\section{Discussion}

We found that the work environment of Danish employees in 1990-2000 has generally improved, except for in- creases in the proportions of employees with long workhours and with noise exposure. Decreases were found in the proportions of employees with kneeling work posture, skin contact with cleaning agents, and some psychosocial work environment factors (decreasing proportions with low job control and with job insecurity). From a public health point of view, these findings can be judged as encouraging as they suggest that the 
contribution of several work environment factors to the disease burden in the Danish population is declining.

However, from a specific work environment intervention point of view, the trend in the last decade has been less encouraging. The changed distribution of employees with regard to jobs explained most of the decreases in the proportions of employees with low job control and skin contact with cleaning agents. Only two of the observed four encouraging changes took place within jobs, namely, the decrease in kneeling work posture and job insecurity.

For all the factors it is possible that the within-job changes and lack of changes could have been due to the effects of the occupational health system, changes in technology, and changes in the organization of labor. For example, the decrease in job insecurity can probably be ascribed to the economic progress made during the 1990s.

Some trends were not explained by labor-force changes. Increases in workhours, noise exposure, and intense computer use and a decrease in part-time work are therefore of interest both from a general public health point of view and from a work environment intervention point of view. The number of workhours defines the limits for exposure to most work environment factors except job insecurity. Before we discuss our findings in more detail, we need to consider the strengths and weaknesses of the study.

\section{Methods}

This study has some possible drawbacks. First, the exposure information was based on self-reports, which may have been biased by changes in public interest. However, we have no indications of increased reporting due to growing public interest. For example, from 1990 to 2000 the proportion reporting passive smoking at work during at least one-fourth of the workhours dropped from $30 \%$ to $20 \%$ (27), and the proportion reporting violence or threats of violence at work remained at the same level (data not shown) even though these two themes gained public awareness during the last decade. In addition, job data are also based on self-reports. One might speculate that the respondents' reporting of "neighboring" job titles (such as clerks, computer professionals, and managers) would change independently of job content and lead to irrelevant control for labormarket changes. Our data do not indicate that a large proportion of employees with neighboring job titles change job titles in the course of time. For example, only $1 \%$ of the clerks in 1990 who were still in the labor market in 2000 reported being computer professionals in 2000, and only 5\% reported being managers in 2000 (data not shown). Third, participation in the study decreased. However, contrasts in participation between various groups with respect to age, gender, or region increased slightly (table 3). Especially the increased contrast with respect to region may indicate that lower social classes tended to be increasingly underrepresented in later rounds of the study. However, this increase caused only a slightly measurable tendency towards overreporting beneficial occupational exposures and underreporting harmful occupational exposures.

In addition, our study had several advantages. First, it contained data from three relatively large representative samples. Second, it included information on various occupational exposures that yielded a relatively broad picture of the work environment. Third, it contained job data on the distribution of the labor force and therefore control for labor-force changes was possible. A study that is characterized by these traits has the possibility to follow changes in the work environment and analyze the possible relation of these changes with labor-force changes.

\section{Trends in the Danish work environment}

In the following text we discuss labor-force changes and changes in the Danish work environment with emphasis on part-time work, low job control, noise, and cleaning.

Labor-force changes. This study found that jobs with a decreasing proportion of the labor force were clerks, cleaners, textile workers, and military personnel. Furthermore, it found an increase in the proportion of academics, computer professionals, and managers. Only a quarter of the decrease in the number of cleaners was explained by the decrease in part-time work (data not shown). A decrease in part-time work would lead to a smaller number of people holding full-time jobs if the same total number of workhours in that job is carried out. A major part of the decrease in the number of cleaners may be explained by increasing efforts (eg, contracting out) to reduce costs in this labor intense industry. It seems that the increasing use of computers is related to the decrease in the number of clerks and the increase in the number of computer professionals. The move out of the textile industry (to, eg, Poland) explains the decrease in textile workers, and the cuts in defense budgets have led to the decrease in military workers. The increase in the number of academics can be ascribed to the increased number of newly qualified academics. The increased number of managers is unexplained. Perhaps an increased functional specialization of organizations has led to more managerial positions. Perhaps our results reflect only a formal upgrading of job titles.

Part-time work. The observed decrease in part-time work in Denmark seems to be almost unique in a European context. In the Eurostat study (4), only Finland and Denmark had increases in workhours, Sweden had no changes, 
and all other countries had considerable decreases. Our analyses show that part-time work decreased also in jobs in which part-time work used to be more prevalent, such as among cleaners, nurses, primary school teachers, and clerks. In these traditional female jobs, the consequence is that the individual exposure to several work environment factors is stronger today than in the past. It should be noted, however, that Danish agreements in the labor market do not make part-time work easily available and that the welfare system provides day care to almost all children from 2 to 6 years of age.

Low job control. The observed proportion of employees with low job control decreased. This development was also found when we looked at the average of the job control scale, which increased over time (data not shown). In Finland, developments occurred in the opposite direction $(2,28)$, and in Sweden no changes (1, 3 , see also www.scb.se) were found. Two analyses of one of the latter studies found that the absence of change was a result of an increase in skill discretion (www.scb.se) and a decrease in job decision latitude (3). This decrease in job decision latitude would have been even greater if an altered distribution of the labor force had been controlled for-on the job level, especially industries such as the primary sector experienced a decrease in job control (3). In our study, the observed decrease was explained by labor-force changes - at the job level, no changes were found. In Denmark, improvements in the psychosocial work environment have been on the agenda of The Danish Working Environment Authority (29), as well as on that of the labor-market organizations, for several years.

Loud noise. The observed increase in loud noise, measured as noise at a level at which one needs to raise one's voice to carry out a conversation, seems to be at least a Nordic trend $(1,2,28)$. Our data show that the increase also took place in nonindustrial jobs, such as jobs in which people were working with children. Among schoolteachers, we found a considerable increase in noise exposure. Noise also increased among preschool teachers (data not shown). Also in Sweden, noise exposure increased among people working with children (1). As our data are self-reported, we are not able to judge whether our results reflect a change in the overreporting of noise exposure among people working with children or whether there are more situations with a noise level at which teachers must raise their voices. There has, in fact, been an increasing awareness of noise exposure among teachers. According to teachers and observers, this awareness is due to changes in the behavior of preschool and school children. In addition, a possible worsened work environment as a whole could have influenced teachers' general views of their work conditions. However, teachers have not experienced less control in the last decade (table 6).

Skin contact with cleaning agents. In Denmark we found an observed decrease in skin contact to cleaning agents, whereas a slight increase was found in Sweden (1). In Denmark, when labor-force changes were controlled for, there was no overall change in exposure to cleaning agents. However, on a job level, there have been changes in exposure. In Denmark, a considerable effort has been made to minimize skin exposure to cleaning agents. This intervention seems, however, only to have been successful among cleaners, not among nurses. It seems relevant to carry out interventions against skin exposure to cleaning agents in occupational groups other than the one most exposed. In the evaluation of the work environment of cleaners, it is worth repeating that parttime work in this group has declined considerably, and this decline has led to more hours of exposure to cleaning work for each individual. Along with the decrease in the number of cleaners, this finding indicates an intensification of cleaners' work.

Changes in work environment factors and priorities of the occupational health system. The observed prevalence of four work environment factors (high job insecurity, kneeling work postures, low job control, and skin contact with cleaning agents) has decreased over the last decade. However, neither the removal of job insecurity nor the lessening of kneeling work postures has been a priority of the occupational health system. From a work environment intervention point of view, only the developments of job control (29) and skin contact with cleaning agents (26) are therefore of interest in the evaluation of changes in the work environment. When laborforce changes were controlled for, the observed-and desired-decreases in low job control and skin contact with cleaning agents disappeared. In addition, noise was the only other work environment factor that has been prioritized by the occupational health system and also included in our study. For it, our findings show an increase. However, only noise above $85 \mathrm{~dB}$ (A) has been mentioned in the national strategic plan (29), whereas the type of noise measured in our study was noise at which one has to raise one's voice in at least one-fourth of the workhours-approximately equivalent to noise levels above $70-75 \mathrm{~dB}$ (A). We are therefore unable to establish whether there has been a desired decrease in exposure to noise above $85 \mathrm{~dB}(\mathrm{~A})$.

\section{Concluding remarks}

Our results indicate that changes in the occupational distribution of the labor force in a country may explain at least some possible observed trends in the prevalence of work environment factors. In our study, all the desired 
beneficial overall trends in Denmark were explained by labor-force changes. This finding suggests that none of the beneficial trends of the selected factors studied can to be attributed to work environment intervention.

When intervention is evaluated on a national level, labor-force changes should be measured in order to control for such changes in analyses of trends in the work environment. In addition, knowledge of labor-force changes may help to predict the work environment of the future.

\section{Acknowledgments}

The 1990 round of the Danish Work Environment Cohort Study was partly funded by the Danish Health Insurance Fund and by the Danish Work Environment Fund (grant 1989-04). The 1995 round was funded by the Danish governmental research program concerning repetitive monotonous work. The 2000 round was funded by the Danish Working Environment Authority and the Ministry of Labor.

\section{References}

1. Statistics Sweden. Arbetsmiljön 1999 [Work environment 1999], Stockholm: Statistics Sweden; 2000.

2. Piirainen H, Elo AL, Hirvonen M, Kauppinen K, Ketola R, Laitinen H, et al. Työ ja terveys-haastattelututkimus 2000 [Work and health survey 2000]. Helsinki: Finnish Institute of Occupational Health; 2000.

3. le Grand C, Szulkin R, Tåhlin M. Har jobben blivit bättre? En analys av arbetsinnehållet under tre decennier [Have the jobs become better? An analysis of job content during three decades]. In: Fritzell J, Gähler M, Lundberg O, editors. Välfärd och arbete i arbetslöshetens årtionde [Welfare and work in the decade of unemployment]. Stockholm: Fritzes offentliga publikationer; 2001.

4. Eurostat. Eurostat yearbook. Luxembourg: Eurostat; 2001.

5. Xu Y, Bach E, Ørhede E. Occupation and risk for the occurence of low-back pain (LBP) in Danish employees. Occup Med 1996;46:131-6.

6. Xu Y, Bach E, Ørhede E. Work environment and low-back pain: the influence of occupational activities. Occup Environ Med 1997;54:741-5.

7. Bøggild H, Burr H, Tüchsen F, Jeppesen HJ. Work environment of Danish shift and day workers. Scand J Work Environ Health 2001;27:97-105.

8. Borg V, Kristensen TS, Burr H. Work environment and changes in self-rated health: a five year follow-up study. Stress Med 2000;16:37-47.

9. Borg V, Kristensen TS. Social class and self-rated health: can the gradient be explained by differences in life style or work environment? Soc Sci Med 2000;51:1019-30.

10. Feveile H, Jensen C, Burr H. Risk factors for neck-shoulder and wrist-hand symptoms in a 5-year follow-up study of 3990 employees in Denmark. Int Arch Occup Environ Health 2002;75:243-51.

11. Tüchsen F, Hannerz H, Burr H, Lund T, Krause N. Risk factors predicting hip pain in a 5-year prospective cohort study. Scand J Work Environ Health 2003;29:35-9.
12. Lund T, Borg V. Work environment and self-rated health as predictors of remaining in work 5 years later among Danish employees 35-59 years of age. Exp Aging Res 1999;25:429-34.

13. Tüchsen F, Krause N, Hannerz H, Burr H, Kristensen TS. Standing at work and varicose veins. Scand J Work Environ Health 2000;26:414-20.

14. Netterstrøm B, Nielsen FE, Kristensen TS, Bach E, Møller L. The relationship between job strain and development of myocardial infarction: a case control study. Occup Environ Med 1999;56:339-42.

15. Skov T, Deddens J, Petersen MR, Endahl L. Prevalence proportion ratios: estimation and hypothesis testing. Int $\mathrm{J}$ Epidemiol 1998;27:91-5

16. Statistics Denmark. Befolkningen i kommunerne 1/1 2001, bilag 2 [The population in municipalities January 1 2001, enclosure 2]. Copenhagen: Statistics Denmark; 2001.

17. The Directorate of Labor. Dansk fagkode [The Danish job classification], Copenhagen: The Directorate of Labor; 1986.

18. Punnett L, Bergqvist U. Upper extremity disorders in video display unit operators. In: Cherniack M, editor. Office ergonomics. Philadelphia (PA): Hanley \& Belfus Inc; 1999. p 11324. Occupational medicine: state of the art reviews, vol 14.

19. Schnall PL, Landsbergis PA, Baker D. Job strain and cardiovascular disease. Ann Rev Public Health 1994;15:381-411.

20. Hemmingway H, Marmot M. Psychosocial factors in the aetiology and prognosis of coronary heart disease: systematic review of prospective cohort studies. BMJ 1999;318:1460-7.

21. de Jonge J, Kompier MAJ. A critical examination of the demand-control-support model from a work psychological perspective. Int J Stress Manage 1997;235-58.

22. Virtanen M, Kivimaki M, Elovainio M, Vahtera J. Selection from fixed term to permanent employment: prospective study on health, job satisfaction, and behavioural risks. J Epidemiol Community Health 2002;56:693-9.

23. Sverke M, Hellgren J, Naswall K. No security: a meta-analysis and review of job insecurity and its consequences. J Occup Health Psychol 2002;7:242-64.

24. Wood PD. Physical activity, diet, and health: independent and interactive effects. Med Sci Sports Exerc 1994;26:838-43.

25. Kirkeskov Jensen L, Eenberg W. Occupation as a risk factor for knee disorders. Scand J Work Environ Health 1996;22:165-75.

26. Blangsted AK, Christiansen J, Flyvholm MA, Nørby H, Søgaard K, Vinzents P. Værktøj til arbejdsmiljøvurdering af rengøringsydelser. Etablering af model for forhåndsvurdering af arbejdsmiljøbelastninger til brug ved afgivelse af udbud og tilbud på rengøringsydelser [Tool for work place assesment of cleaning services: establishment of a model to early assessment of work environment consequences when supplying and demanding cleaning services]. Copenhagen: National Insititute of Occupational Health; 2000.

27. Burr H, Villadsen E. Fysisk, termisk og kemisk arbejdsmiljø. Arbejdsmiljø i Danmark 1990-2000 [Physical, thermal and chemical work environment: work environment in Denmark 1990-2000]. Copenhagen: National Institute of Occupational Health; 2002.

28. Piirainen H, Elo AL, Kankaanpää E, Laitinen H, Lindström $\mathrm{K}$, Luopajärvi T, et al. Työ ja terveys - haastattelututkimus 1997 [Work and health survey 1997]. Helsinki: Finnish Institute of Occupational Health; 1997.

29. Hasle P, Møller N. The action plan against repetitive workan industrial relation strategy for improving the working environment. Hum Factors Ergon Manuf 2001;11:131-44.

Received for publication: 25 October 2002 